\title{
The Influence of Finger Puppet Media on Students' High Level of Thinking Ability in Elementary School
}

\author{
Risma Nuriyanti ${ }^{1}$, Abih Gumelar ${ }^{2}$ \\ ${ }^{1}$ Institut Pendidikan Indonesia, ${ }^{2}$ Universitas Pendidikan Indonesia \\ nuriyantirisma@gmail.com
}

\section{Article History}

accepted 05/11/2020

approved $10 / 11 / 2020$

published 01/02/2021

\begin{abstract}
The low level of thinking ability of elementary school students is one of the problems that need to be considered. This study aims to know the influence of finger puppet media on students' high level of thinking ability in elementary school. The method used is a quarquis of nonequivalent control group design experiments. The population in this study was fourth grader in one of bandung elementary school which numbered 47 students and divided into two classes, namely experimental class and control class. The results showed there was a significant difference between posttest experiment class and control class. From these results it can be concluded that finger puppet media has a significant influence on students' high level of thinking ability in elementary school. Thus, students get meaningful learning and teachers get learning media that is able to improve students' high level of thinking ability which is assessed from the ability to analyze, which includes 3 indicators, namely determining the theme, determining the main idea, and determining the content of the story message.
\end{abstract}

Keywords: finger puppet media, higher order thinking skilss, elementary school

\begin{abstract}
Abstrak
Rendahnya kemampuan berpikir tingkat tinggi siswa sekolah dasar menjadi salah satu permasalahan yang perlu diperhatikan. Penelitian ini bertujuan untuk mengatahui pengaruh media finger puppet terhadap kemampuan berpikir tingkat tinggi siswa di sekolah dasar. Metode yang digunakan adalah kuasi eksperimen desain nonequivalen control group design. Populasi pada penelitian ini adalah siswa kelas empat di salah satu SD kota Bandung yang berjumlah 47 siswa dan terbagi ke dalam dua kelas yaitu kelas eksperimen dan kelas kontrol. Hasil penelitian menunjukkan terdapat perbedaan yang signifikan antara posttest kelas eksperimen dan kelas control. Dari hasil tersebut dapat disimpulkan bahwa media finger puppet berpengaruh secara signifikan terhadap kemampuan berpikir tingkat tinggi siswa di sekolah dasar. Dengan demikian siswa mendapatkan pembelajaran yang bermakna dan guru memperoleh media pembelajaran yang mampu meningkatkan kemampuan berpikir tingkat tinggi siswa yang dinilai dari kemampuan menganalisis yakni meliputi 3 indikator yaitu menentukan tema, menentukan ide pokok, dan menentukan isi pesan cerita.
\end{abstract}

Kata kunci: media finger puppet, kemampuan berpikir tingkat tinggi, sekolah dasar

Social, Humanities, and Education Studies (SHEs): Conference Series https://jurnal.uns.ac.id/shes

p-ISSN 2620-9284

e-ISSN 2620-9292 


\section{PENDAHULUAN}

Kemampuan berpikir tingkat tinggi merupakan suatu aktivitas berpikir siswa yang melibatkan level kognitif hierarki tingkat tinggi dari Taksonomi Bloom, meliputi menganalisis, mengevaluasi, dan mencipta (Anderson \& Karthwohl, 2015). Hal ini sesuai dengan tuntutan pendidikan abad 21 salah satunya mendorong setiap individu untuk memiliki kemampuan berpikir tingkat tinggi. Sejalan dengan pendapat Sajidan \& Afandi (2018) bahwa kompetensi lulusan yang menguasai keahlian berpikir menjadi sangat penting sesuai dengan dinamika kebutuhan global saat ini. Untuk mengakomodasi pergeseran proses pembelajaran abad 21 maka seorang guru dituntut untuk mengembangkan kreativitasnya dalam proses pembelajaran (Zubaidah, 2016). Namun pada kenyataannya saat ini guru belum membiasakan siswa untuk melatih kemampuan berpikir tingkat tinggi, melainkan hanya melatihkan siswa berpikir tingkat rendah yang ditandai dengan pengetahuan, pemahaman, dan penerapan atau aplikasi sudah berjalan dengan baik.

Berdasarkan temuan diilapangan, banyak permasalahan terkait kemampuan berpikir tingkat tinggi siswa. khususnya pada pembelajaran bahasa Indonesia dalam kemampuan menganalisis cerita. Siswa masih kesulitan menemukan pesan tersirat pada sebuah cerita. Masalah yang paling banyak ditemui adalah siswa masih bingung dalam menentukan tema cerita dan menentukan simpulan pada cerita. Hal tersebut berkaitan dengan kemampuan literasi dan kemampuan berpikir tangkat tinggi siswa yang masih rendah. Sunendar (2020) menyatakan bahwa kemampuan literasi siswa di Indonesia berada pada rangking 72 dari 74 dari seluruh negara. Sedangkan kemampuan berpikir tingkat tinggi di Indonesia menurut surveyyang bermarkas di London, melaporkan bahwa "Global Index of cognitive skills and educational attainment" Indonesia menempati rangking terbawah dari 40 negara yang berpatisipasi (Learning Curve, 2014).

Banyak para peneliti yang menyikapi dengan munculnya pencapaian Pendidikan Indonesia tersebut dengan melaksanakan penelitian terkait kemampuan berpikir tingkat tinggi. Fitri et al., (2018) menyatakan bahwa model project based learning berpengaruh terhadap kemampuan berpikir tingkat tinggi siswa yang ditunjukkan dengan nilai rata-rata siswa yang mencapai kriteria ketuntasan minimal. Namun untuk keefektifan penerapan model pembelajaran harus diimbangi dengan penggunaan media sebagai sarana menyampaikan materi kepada siswa. Hal tersebut sejalan dengan pendapat Ekayani (2017) bahwa dengan menerapkan media pembelajaran, siswa akan mudah mengingat dan menyerap materi pembelajaran yang disampaikan oleh guru. Pratiwi \& Puspito Hapsari (2020) menyatakan dengan memanfaatkan media youtube dapat meningkatkan kemampuan berpikir tingkat tinggi pada pembelajaran bahasa Indonesia di sekolah dasar. Namun pada saat pelaksanaannya, penggunaan media youtube ini terkedala dengan ketersediaan sarana prasana yang dimiliki oleh siswa. Maka dari itu dibutuhkan media yang lebih mudah diimplementasikan (Nugraheni, 2017)

Mengingat hal tersebut, salah satu media pembelajaran yang mungkin menjadi salah satu alternatif yaitu media finger puppet yang diperkirakan cocok untuk mengajar dalam proses peningkatan kemampuan berpikir tangkat tinggi siswa. Media origami finger puppet ini disebut juga sebagai alat peraga yang digunakan oleh guru dan berfungsi membantu guru dalam proses mengajarnya dan menstimulasi siswa pada aktivitas berpikir tingkat tinggi (Yaumi \& Syafe'l, 2012). Penggunaan media origani finger puppet ini berasal dari Bahasa jepang yaitu oru yang berarti melipat dan kami atau gami yang berarti kertas (Amiliya, Wilsom, Solfiah, 2015). Pada pelaksanaannya, melipat kertas merupakan aktivitas seni yang mudah dibuat menyenangkan sehingga pembelajaran pun tidak monoton.

Tujuan dari kajian ini yaitu untuk membtuktikan pengaruh media finger puppet terhadap kemampuan berpikir tingkat tinggi siswa khususnya pada pembelajaran 
bahasa Indonesia yakni dalam menganalisis cerita. Hasil dari kajian ini akan menjadi referensi baik untuk guru dan peneliti yang akan menkaji terkait media origami finger puppet dan kemampuan berpikir tingkat tinggi siswa sekolah dasar.

\section{METODE}

Penelitian ini menggunakan pendekatan kuantitatif dengan metode penelitian kuasi eksperimen rancangan nonequivalent control group design. Penelitian eksperimen kuasi ini digunakan untuk mengetahui perbedaan kemampuan kelas yang diberi perlakuan dan kelas yang tidak diberi perlakuan. Keduanya kemudian diberi preetest untuk mengetahui keadaan awal dan perbedaan antara kelompok eksperimen dan kelompok kontrol. Berikut gambaran dari desain penelitian tersebut tertera pada tabel 1

\section{Tabel 1 Desain Penelitian Nonequivalent Control Group Design}

\begin{tabular}{lll}
\hline $\mathrm{O}_{1}$ & $\mathrm{X}$ & $\mathrm{O}_{2}$ \\
\hline $\mathrm{O}_{3}$ & - & $\mathrm{O}_{4}$ \\
\hline
\end{tabular}

$\begin{array}{ll}\text { Keterangan } \\ \mathrm{O}_{1} & \text { : Preetest eksperimen } \\ \mathrm{O}_{2} & \text { : Posttest eskperimen } \\ \mathrm{O}_{3} & \text { : Preetest kontrol } \\ \mathrm{O}_{4} & \text { : Posttest kontrol } \\ \mathrm{X} & \text { : treatment } \\ - & \text { : tidak dilakukan treatment }\end{array}$

Adapun populasi dalam penelitian ini adalah seluruh siswa sekolah dasar kelas empat di Kota Bandung. Sampel yang dipilih adalah siswa kelas empat di salah satu SD kota Bandung yang berjumlah 47 siswa, 24 siswa dari kelas eksperimen dan 23 siswa dari kelas kontrol. teknik pemilhan sampel menggunakan teknik purposive sampling karena penelitian kuasi eksperimen terdapat dua kelompok yang tidak dipilih secara random (Sugiono, 2016; Cresswell; 2013 dan Crano, Brewer, \& Lac 2014)

Instrumen penelitian yang digunakan yaitu tes bentuk uraian, digunakan untuk menilai kemampuan berpikir tingkat tinggi yakni menganalisis cerita (C4) yang dinilai berdasarkan tiga aspek yakni (1) menentukan tema; (2) menentukan ide pokok cerita; (3) menentukan isi pesan cerita. Validasi ahli dilakukan oleh tiga orang ahli, seorang ahli Pendidikan Bahasa Indonesia, soerang ahli perkembangan dan seorang ahli pembelajaran untuk menguji kesesuaian soal denga nisi materi pelajaran (Sugiyono, 2016). Setelah diperbaiki berdasarkan hasil validasi selanjutrnya dilakukan validasi empiris untuk menguji realibilitasnya dan diperoleh $r=0,77$

Semua jawaban dari 47 siswa sekolah dasar kelas empat dimasuka ke dalam Ms-Program Excel dan dikelompokkan serta di berikan skor dari setiap indiktaornya. Selanjutrnya, data diperoleh dianalisis secara deskriptif. Untuk memperoleh hipotesis dilakukan analisis statistic dengan uji perbedaan yaitu dengan uji-t dengan menggunakan software SPSS for Windows versi 22. Analisis diarahlan pada perbandingan pretest dan posttest kelas eksperimen dan kelas control.

\section{HASIL DAN PEMBAHASAN}

Pada penelitian ini pembelajaran dilaksanakan 5 kali pertemuan dengan menggunakan aplikasi zoom meeting dikarenakan penelitian dilaksanakan saat pandemic covid-19. Sebelumnya siswa diberikan pretest untuk mengetahui 
kemampuan awal siswa baik di kelas eksperimen maupun di kelas control. Dari hasil pretest didapatkkan nilai rata-rata kelas eksperimen yaitu 39 dan kelas control yaitu 44,1 . Nilai tersebut masih dikategorikan kurang. Hal tersebut disebabkan karena siswa kurang minat dan motivasi dalam menyimak cerita yang disampaikan sehingga proses analisis menjadi terhambat. Aritonang (2008) menyatakan bahwa minat dan motivasi siswa dalam belajar sangat berpengaruh terhadap hasil belajar siswa.

Persamaan kemampuan awal siswa baik di kelas eksperimen maupun di kelas control menjadi alasan peneliti untuk memberikan perlakuan. Perlakuan yang diberikan kepada masing-masing kelas ini adalan perlakuan yang berbeda. Pada kelas eksperimen perlakuan perlakuan yang diberikan yaitu dengan menggunakan media finger puppet. Sedangkan pada kelas control tanpa menggunakan media pembelajaran. Pada tahap pemberian perlakuan ini siswa memperoleh pembelajaran sebanyak lima kali pertemuan. Setelah kedua kelas diberikan perlakuan yang berbeda, kemudian dilaksanakan tes akhir atau posttest. Setelah dilakukan posttest pada kedua kelas. Hasil posttest menunjukkan perubahan nilai rata-rata kemampuan berpikir tingkat tinggi pada aspek menganalisis (C4) mengalami kenaikan dibandingkan sebelumnya. Nilai rata-rata posttest kelas eksperimen yang diberikan perlakuan dengan menggunakan media finger puppet adalah 71,1 , sedangkan kelas control yang tidak mendapatkan perlakuan memperoleh 50,26.

Deskripsi data sebagaimana diperoleh diatas menunjukkan adanya peningkatan berpikir tingkat tinggi pada ranah kognitif C4 yang dilihat dari tiga terangkum pada table berikut.

Tabel 1 . Rerata Skor Pretest dan Posttest

\begin{tabular}{|c|c|c|c|c|}
\hline $\begin{array}{l}\text { Ranah } \\
\text { Konginif }\end{array}$ & Aspek penilaian & & Eskperimen & Kontrol \\
\hline \multirow[t]{6}{*}{ Menganalisis } & Menentukan tema & Pretest & 2,25 & 2,0 \\
\hline & & Posttest & 3,58 & 2,9 \\
\hline & Menentukan Ide pokok & Pretest & 2 & 1,7 \\
\hline & & Posttest & 3,83 & 2,3 \\
\hline & Menentukan Isi pesan Cerita & Pretest & 1,7 & 1,9 \\
\hline & & Posttest & 3,54 & 2,7 \\
\hline
\end{tabular}

Table 1 di atas menunjukkan nilai rerata pretest dan postest setiap aspek mengalami kenaikan baik kelas control maupun kelas eksperimen hampir semua indikator. Akan tetapi kenaikan secara signifikan terjadi pada kelas eksperimen yang diberikan perlakuan dengan penggunaan media pembelajaran finger puppet. Indicator menentukan ide pokok memiliki skor yang lebih besar dibandingkan indicator menentukan tema dan isi pesan cerita. Sementara indicator menentukan isi pesan cerita lebih kecil dari indicator yang lainnya.

Untuk mengetahui nilai signifikansi perbedaan rerata skor secara keseluruhan dari indicator kemampuan berpikir tingkat tinggi dari aspek menganalisis (C4) maka dilakukan uji perbedaan rerata. Untuk keperluan uji perbedaan rerata digunakan uji paramentrik (Uji-t) dengan SPSS versi 22, hasil statistic disajikan dalam tebal 2. 
Tabel 2. Uji Hipotesis

\begin{tabular}{|c|c|c|c|}
\hline Hasil & $\mathrm{Df}$ & Pretest & Posttest \\
\hline & & \multicolumn{2}{|c|}{ Sig.(2-tailed) } \\
\hline $\begin{array}{l}\text { Kemampuan Berpikir Tingkat Tinggi C4 } \\
\text { (Menganalisis) }\end{array}$ & 45 & 5.297 & 0.00 \\
\hline
\end{tabular}

Table 2 menunjukkan nilai signifikansi pretest lebih dari 0,05 yakni 5,297, maka dapat disimpulkan bahwa tidak terdapat perbedaan antara kelas eksperimen dan kelas control. Berbeda dengan nilai signifikansi posttest kurang dari 0,05 yakni 0,00 , hal ini berarti posttest kemampuan berpikir tingkat tinggi C4 (menganalisis) di kelas eksperimen yang mendapat perlakuan dengan menggunakan media finger puppet dan kelas control yang tidak mendapatkan perlakuan terdapat perbedaan atau terdapat pengaruh yang signifikan

Berdasarkan hasil tersebut ditemukan bahwa pemberian perlakuan dengan menggunakan media finger puppet berpengaruh terhadap kemampuan berpikir tingkat tinggi siswa. Hal ini karena media finger puppet berpengaruh positif terhadap kemampuan berpikir tingkat tinggi siswa terutama pada ranah kognitif $\mathrm{C} 4$ (menganalisis).

Rerata pretest dan posttest kemampuan berpikir tingkat tinggi pada ranah C4 (menganalisis) siswa sekolah dasar terkait pada materi bahasa Indonesia pada setiap indikatornya (menentukan tema, menentukan ide pokok, menentukan isi pesan) adalah bervariasi. Apa yang diperoleh dari hasil analisis deskriptif di atas lebih diperjelas dengan hasil uji statistic. Hasil uji statistic menunjukkan kemampuan berpikir tingkat tinggi siswa sekolah dasar sebelum dan sesudah menggunakan media finger puppet adalah berbeda. Ada peningkatan rerata skor kemampuan berpikir tingkat tinggi siswa di sekolah dasar.

Dari table 1 di atas tergambar bahwa pengalaman berlajar sebelumnya belum cukup membekali kemampuan berpikir tingkat tinggi siswa tentang menentukan tema, menentukan ide pokok dan menentukan isi pesan. Indicator menentukan isi pesan cerita memiliki rerata lebih kecil dari indicator yang lain. Hal tersebut dikarenakan siswa masih kesulitan dalam menentukan isi pesan dalam cerita terlebih pesannya tidak tersurat akan tetapi secara tersirat. Namun melihat hasil dari perolehan skor menentukan isi pesan mencapai 3,54 masih tergolong cukup. Oleh karenanya tidak diperlukan usaha lebih untuk membuktikan pengaruh media finger puppet terhadap kemampuan berpikir tingkat tinggi siswa.

Penggunaan media finger puppet telah terbukti berpengaruh terhadap kemampuan berpikir tingkat tinggi siswa kelas empat sekolah dasar terutama pada mata pelajaran bahasa Indonesia tentang cerita. Berasarkan hasil analisis deskriptif dapat disimpulkan bahwa kemampuan berpikir tingkat tinggi siswa sekolah dasar khususnya di kelas empat dengan indicator menentukan tema, menentukan ide pokok, dan menentukan isi pesan dapat dipengaruhi oleh media finger puppet dimana siswa menyimak cerita dengan bantuan media finger puppet. Hal ini sesuai yang diungkapkan oleh Wedana, dkk (2019); Jenkins, Beckh (1942) yang mengungkapkan bahwa penggunaan finger puppet dalam pembelajaran tidak hanya meningkatkan minat dan motivasi siswa dalam belajar, akan tetapi mampu meningkatkan kemampuan berpikir anak terutama dalam menyimak cerita serta menganalisis pointpoint penting cerita.

\section{SIMPULAN}

Dari hasil penelitian ini disimpulkan bahwa pengalaman belajar sebelumnya belum cukup melatih siswa untuk berpikir tingkat tinggi terutama dalam pembelajaran bahasa Indonesia. Pembelajaran dengan menggunakan media finger puppet dapat berpengaruh terhadap kemampuan berpikir tingkat tinggi siswa yang ditunjukkan 
adanya peningkatan dari setiap indicator menganalisis suatu cerita yaitu menentukan tema, menentukan ide pokok, dan menentukan isi pesan cerita. Namun demikian, namun peningkatannya masih dalam kategori sedangan. Indicator menentukan ide pokok memiliki peningkatan lebih besar dibandingkan indicator yang lain. Pembelajaran dengan menggunakan media finger puppet mampu berpengaruh terhadap kemampuan berpikir tingkat tinggi siswa.

\section{DAFTAR PUSTAKA}

Anderson, L.W. \& Krathwohl, D.R. (Eds). 2015. Kerangka landasan untuk pembelajaran, pengajaran, dan asesmen: revisi taksonomi pendidikan Bloom.(Terjemahan Agung Prihantoro). Yogyakarta: Pustaka Pelajar.

Amiliya, Reni A., et al. "Pengaruh Bercerita dengan Media Boneka Jari Berbahan Origami terhadap Kemampuan Menyimak Anak Usia 4-5 Tahun di Tk Angrek Kecamatan Tapung Kabupaten Kampar." Jurnal Online Mahasiswa Fakultas Keguruan dan IImu Pendidikan Universitas Riau, vol. 2, no. 2, Oct. 2015, pp. 1-7.

Aritonang, K. T. (2008). Minat dan motivasi dalam meningkatkan hasil belajar siswa. Jurnal pendidikan penabur, 7(10), 11-21.

Cresswell, J. W. (2013). Research Design: Pendekatan Kualitatif, Kuantitatif, dan Mixed. Yogyakarta: Pustaka Pelajar

Crano, W. D., Brewer, M. B., \& Lac, A. (2014). Principles and methods of social research. Routledge.

Ekayani, P. (2017). (2017). Pentingnya Penggunaan Media. March. https://www.researchgate.net/publication/315105651

Fitri, H., Dasna, W., \& Dasar, P. (2018). Pengaruh Model Project Based Learning (PjBL) Terhadap Kemampuan Berpikir Tingkat Tinggi Ditinjau dari Motivasi Berprestasi Siswa Kelas IV Sekolah Dasar. BRILIANT: Jurnal Riset Dan Konseptual, 3(2), 201-212. https://doi.org/10.28926/briliant

Jenkins, R. L., \& Beckh, E. (1942). Finger puppets and mask making as media for work with children. American Journal of Orthopsychiatry, 12(2), 294.

Nugraheni, N. (2017). Penerapan Media Komik Pada Pembelajaran Matematika Di Sekolah Dasar. Refleksi Edukatika: Jurnal IImiah Kependidikan, 7(2).

Pratiwi, B., \& Puspito Hapsari, K. (2020). Analisis Kemampuan Berpikir Tingkat Tinggi Melalui Pemanfaatan YouTube Sebagai Media Pembelajaran Bahasa Indonesia. Jurnal IImiah Sekolah Dasar, 4(2), 282. https://doi.org/10.23887/jisd.v4i2.24238

Sugiono. (2016). Metode Penelitian: Kuantitatif, Kualitatif, dan R\&D. Bandung: alfabeta

Wedana, I. M. L., Suarnajaya, W., \& Adnyani, L. D. S. (2019). The Effect Of Puppets as Teaching Media on the Speaking Competency. Jurnal Penelitian dan Pengembangan Sains dan Humaniora, 3(2), 128-133.

Yaumi dan Syafei. 2012. Modul 1 Media \& Teknoogi dalam Pembelajaran, Fak. Tarbiah UIN Alauddin Makassar.

Zubaidah, S. (2016, December). Keterampilan abad ke-21: Keterampilan yang diajarkan melalui pembelajaran. In Seminar Nasional Pendidikan dengan Tema "isu-isu strategis pembelajaran MIPA Abad (Vol. 21, No. 10). 